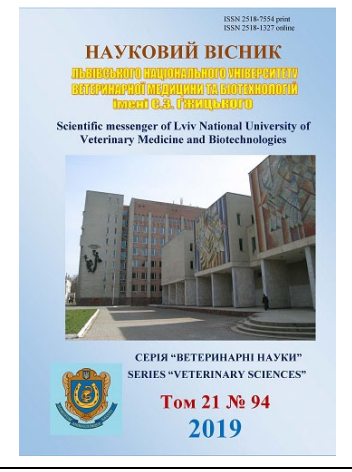

\author{
Науковий вісник Иьвівського національного університету \\ ветеринарної медицини та біотехнологій імені С.3. Гжицького. \\ Серія: Ветеринарні науки \\ Scientific Messenger of Lviv National University \\ of Veterinary Medicine and Biotechnologies. \\ Series: Veterinary sciences
}

UDC 619:619.661

\title{
Influence of cadmium sulfate at different doses on the functional state of the liver of laying chicken
}

\author{
A.Y. Ostapyuk, B.V. Gutyj \\ Stepan Gzhytskyi National University of Veterinary Medicine and Biotechnologies Lviv, Ukraine
}

Article info

Received 13.04.2019

Received in revised form 13.05.2019

Accepted 14.05.2019

Stepan Gzhytskyi National University of Veterinary Medicine and Biotechnologies Lviv, Pekarska Str., 50, Lviv, 79010, Ukraine. Tel.: +38-068-136-20-54 E-mail: bvh@ukr.net
Ostapyuk, A.Y., \& Gutyj, B.V. (2019). Influence of cadmium sulfate at different doses on the functional state of the liver of laying chicken. Scientific Messenger of Lviv National University of Veterinary Medicine and Biotechnologies. Series: Veterinary sciences, 21(94), $103-108$. doi: $10.32718 /$ nvlvet9419

The article presents the results of studies on the influence of cadmium sulfate in different doses on the organism of poultry. Absorbed cadmium accumulates in the liver as a complex with metallothionein. The purpose of the work was to find out the effect of cadmium sulfate in doses of 2 and $4 \mathrm{mg} / \mathrm{kg}$ of body weight on the functional state of the liver of chicken. For research, three groups of birds were formed: control and two experimental. The control group of chickens were in the usual diet, they were fed with forage and were given water without introducing cadmium sulfate. To the drinking water of chickens of experimental groups for 30 days, added cadmium sulfate in doses: the first group - $2 \mathrm{mg} / \mathrm{kg}$, the second group - $4 \mathrm{mg} / \mathrm{kg} \mathrm{body}$ weight. The conditions for keeping chickens and the microclimate parameters in the room for all bird groups were similar. Blood from the chickens was taken from the subclavian vein in periods: before the dasg was given and on the first, seventh, fourteenth, twenty-first and thirtieth day of the experiment. It was determined that the presentation of cadmium sulfate in doses of 2 and $4 \mathrm{mg} / \mathrm{kg}$ of body weight of cows, which contributed to a violation of the functional state of the liver, as evidenced by the increased activity of aminotransferases in their blood serum. The activity of alanine and aspartate aminotransferase was higher in serum of blood of chickens in the second experimental group at 21st and 30th days of the experiment. The high activity of aminotransferases in the blood serum of chickens for cadmium loading indicates destructive processes in the liver that cause an increase in the release of aminotransaminases from cellular organelles in the blood of experimental poultry. Thus, the obtained results indicate an increase in destructive processes in the body of chickens for cadmium loading.

Key words: toxicology, cadmium sulfate, laying chicken, aminotransferase, liver.

\section{Вплив сульфату кадмію у різних дозах на функціональний стан печінки курей-несучок}

А.Ю. Остап’юк, Б.В. Гутий

Львівський національний університет ветеринарної медицини та біотехнологій імені С.3. Гжицького, м. Львів, Украӥна

У статті наведено результати досліджень впливу сульфату кадмію у різних дозах на організм птиці. Абсорбований кадмій накопичується в печіниі у вигляді комплексу з металотіонеїном. Метою роботи було з'ясували вплив кадмію сульфату у дозах 2 i 4 мг/кг маси тіла на функціональний стан печінки курей-несучок. Для досліджень було сформовано три групи птиці: контрольну $і$ дві дослідні. Кури контрольної групи знаходилися на звичайному рачіоні, їм згодовували комбікорм та випоювали воду без внесення сульфату кадмію. До питної води курей дослідних груп протягом 30 діб додавали сульфат кадмію в дозах: периа група - 2 мг/кг, друга група - 4 мг/кг маси тіла. Умови утримання курей та параметри мікроклімату в приміщенні для всіх груп птиці були аналогічними. Кров у курей-несучок відбирали із підкрильцевої вени у періоди: до початку задавання препарату та на периу, сьому, чотирнадияту, двадиять периу та тридияту доби досліду. Встановлено шуо випоювання курям-несучкам сульфату кадмію у дозах 
2 і 4 мг/кг маси тіла, сприяло порушенню функціонального стану печінки, на щуо вказує підвищена активність амінотрансфераз у їх сироватиі крові. Активність аланін- та аспартат-амінотрансферази була вищою у сироватці крові курей другої дослідної групи на 21 та 30 добу досліду. Висока активність амінотрансфераз у сироватиі крові курей за кадмієвого навантаження вказує на деструктивні процеси у печінці, які спричиняють збільшення виходу амінотрансаміназ з клітинних органел у крові дослідної птиці. Таким чином, одержані результати вказують про посилення деструктивних процесів в організмі курей за кадмієвого навантаження. Активність аланін-амінотрансферази зростала більшою мірою чим активність аспартат-амінотрансферази. Це пов'язано з тим, що АлАТ навіть при незначних деструктивних ураженнях мембран гепатоцитів за кадмієвого навантаження, легко виділяється з них $і$ надходить у кров, тоді як АсАТ міститься у мітохондріях гепатоцитів, а тому проникнення даного ензиму у кров ускладнюється ще й тим, щуо крім поверхневої оболонки клітини, даний ензим повинен проникнути ще й через мітохондріальну мембрану, щуо буває при високих дозах кадмію.

\section{Ключові слова: токсикологія, сульфат кадмію, кури-несучки, амінотрансферази, печінка.}

\section{Вступ}

Неконтрольовані надмірні викиди промислових підприємств і автотранспорту, порушення системи внесення добрив, обробки рослин отрутохімікатами, техногенні аварії та інші антропогенні фактори приводять до накопичення важких металів у грунті та рослинах, що негативно впливає на стан здоров'я сільськогосподарських тварин та людини. До найбільш небезпечних забруднювачів навколишнього середовища належить кадмій (Uetani et al., 2005; Nazaruk et al., 2015; Sachko et al., 2016). Упродовж останніх десятиріч зростання вмісту цього металу в грунтах України та інших країн супроводжується нагромадженням $\mathrm{Cd}^{2+}$ у сільськогосподарській продукції та кормах, збільшенням загрози здоров'ю людини i тварин (Hutyi, 2013; Gutyj et al., 2015; Hradovych et al., 2016; Grushanska, 2017).

Кадмій та його сполуки відносяться до імунотоксикантів, які викликають порушення у функціонуванні імунної системи організму, знижують резистентність до інфекцій, сприяють формуванню алергічних, аутоімунних та онкологічних патологій (Ali et al., 1986; Salvatori et al., 2004; El-Refaiy \& Eissa, 2012; Peng et al., 2015; Gutyj, 2015). Особливістю біологічної дії Кадмію $є$ його здатність негативно впливати на здоров'я тварин при тривалому впливі низьких рівнів забруднення у зв'язку з високим коефіцієнтом біологічної кумуляції (до 40 років). Відомо, що кадмій може значною мірою змінювати метаболізм і функції таких ессенціальних елементів, як Цинк, Залізо, Мідь, Марганець, Кальцій, Селен (Ostapyuk \& Gutyj, 2018).

Кадмій шкідливо впливає на життєві системи організму людини і тварин, спричиняючи патологічні зміни у тканинах і органах (нирки, легені, кісткова тканина, органи репродуктивної й ендокринної систем), пригнічуючи процес еритропоезу та функції імунної системи (Fregoneze et al., 1997; Rodríguez et al., 2001; Lu et al., 2005; Liu et al., 2008; Al-Azemi et al., 2010). Порушення, зумовлені тривалим надходженням Кадмію в організм, визначаються рівнем нагромадження $\mathrm{Cd} 2+$ в клітинах і проявом кумулятивної токсичності. Уразливість клітин до дії Кадмію значною мірою залежить від рівня експресії в них генів металозв'язувальних білків - металотіонеїнів (Antonio et al., 1998; Pavan Kumar \& Prasad, 2004; El-Shahat et al., 2009).
Отруєння Кадмієм відбувається при потраплянні його в шлунок або інгаляційним шляхом. Абсорбований кадмій накопичується в печінці та нирках у вигляді комплексу з металотіонеїном.

Саме тому наші дослідження були спрямовані на вивчення впливу Кадмію на функціональний стан печінки курей-несучок.

\section{Матеріал і методи досліджень}

Для досліду було відібрано 24 курки-несучки кросу Хайсекс білий, віком 78 тижнів, 3 яких сформували три групи: контрольну і дві дослідні. Групи формувалися за принципом аналогів (вік і жива маса). Курей різних груп мітили стійкими органічними барвниками. Кури контрольної групи знаходилися на звичайному раціоні, їм згодовували комбікорм та випоювали воду без внесення сульфату кадмію. До питної води курей дослідних груп протягом 30 діб додавали кадмію сульфат в дозах: перша група - 2 мг/кг, друга група - 4 мг/кг маси тіла.

Умови утримання та параметри мікроклімату в приміщенні для всіх груп птиці були аналогічними. Впродовж досліду обліковували кількість спожитого корму і води.

Усі експериментальні втручання та забій тварин проводили 3 дотриманням вимог “Свропейської конвенції про захист хребетних тварин, яких використовують для експериментальних та наукових цілей" (Страсбург, 1985) та ухвали Першого національного конгресу з біоетики (Київ, 2001).

Кров у курей-несучок відбирали із підкрильцевої вени у періоди: до початку задавання кадмію сульфату та на першу, сьому, чотирнадцяту, двадцять першу та тридцяту доби досліду.

У сироватці крові, за допомогою стандартних наборів реактивів фірми "Simko Ltd" (Чехія), визначали активність аспартат-амінотрансферази (АсАТ; КФ 2.6.1.1) та аланінамінотрансферази (АлАТ; КФ 2.6.1.2) уніфікованим динітрофенілгідразиновим методом Райтмана-Френкеля. Метод базується на тому, що після додавання до сироватки крові 2,4 дифенілгідразинового реактиву відбувається переамінування i утворення глутамінової та піровиноградної кислот (АсАТ), або глутамінової та щавелевооцтової кислот (АлАТ) і субстрат забарвлюється у відповідний колір, інтенсивність якого прямопропорційна активності ензиму (Vlizlo, 2012). 
Аналіз результатів досліджень проводили за допомогою пакету програм Statistica 6.0. Вірогідність різниць оцінювали за t-критерієм Стьюдента. Результати середніх значень вважали статистично вірогідними при * $-\mathrm{P}<0,05, * *-\mathrm{P}<0,01, * * *-\mathrm{P}<$ 0,001 (ANOVA).

\section{Результати та їх обговорення}

Оскільки кадмій негативно впливає на роботу печінки, тому необхідно дослідити функціональний стан печінки. У крові курей, визначали активність амінотрансфераз, адже дані ензими відображають функціональний стан печінки (Hariv \& Gutyj, 2016; Gutyj et al., 2017). Відомо, що амінотрансферази беруть участь у процесах переамінування. Вони переносять аміногрупи від амінокислот до кетокислот (Gutyj et al., 2018). Одним із ензимів, які належать до даної групи амінотрансфераз, є аланін-амінотрансфераза. Активність цього ензиму за кадмієвого навантаження наведена у таблиці 1. Аланін-амінотрансфераза - це особливий ензим, який входить до класифікації трансфераз, основна функція якого - каталізація оборотних перено- сів аміногрупи $\mathrm{NH}_{2}$ безпосередньо 3 амінокислоти аланіну для альфа-кетоглутарату, що призводить до створення піровиноградної кислоти та глутамату. Аланін-амінотрансфераза $є$ одним 3 основних показників ураження клітин печінки. 3 наведених у таблиці 1 даних видно, що активність аланінамінотрансферази, до випоювання сульфату кадмію, у сироватці крові курей була у межах величин $0,30 \pm 0,009-0,32 \pm 0,005$ ммоль/г/л. Після випоювання згаданого вище токсиканту, активність ензиму, у птиці дослідних груп зростала. Встановлено, що за кадмієвого навантаження активність даного ензиму вірогідно зростає вже з 14 доби досліду, де відповідно у першої дослідної групи курей вона зросла на 15\%, а у другої - на 21\%. На 21 добу досліду активність аланін-амінотрансферази коливалася у межах $0,40 \pm 0,008-0,45 \pm 0,009$ ммоль/г/л, тоді як у контрольної групи курей даний показник становив 0,31 0,007 ммоль/г/л. На 30 добу досліду активність АлАТ у сироватці крові першої дослідної групи була вищою на 26,7\%, а у другої дослідної групи - на 43\% відносно показників контрольної групи курей.

\section{Таблиця 1}

Активність амінотрансфераз сироватки крові курей-несучок за кадмієвого навантаження $(\mathrm{M} \pm \mathrm{m}, \mathrm{n}=8)$

\begin{tabular}{|c|c|c|c|c|c|}
\hline \multirow{2}{*}{ Дослідні групи } & \multirow{2}{*}{ До випоювання } & \multicolumn{4}{|c|}{ Доби дослідження } \\
\hline & & 7 & 14 & 21 & 30 \\
\hline \multicolumn{6}{|c|}{ АлАТ, ммоль/г/л } \\
\hline $\mathrm{K}$ & $0,31 \pm 0,008$ & $0,30 \pm 0,006$ & $0,33 \pm 0,005$ & $0,31 \pm 0,007$ & $0,30 \pm 0,005$ \\
\hline Д1 & $0,32 \pm 0,005$ & $0,34 \pm 0,009^{*}$ & $0,38 \pm 0,007 * * *$ & $0,40 \pm 0,008 * * *$ & $0,38 \pm 0,008 * * *$ \\
\hline Д2 & $0,30 \pm 0,009$ & $0,36 \pm 0,007^{* *}$ & $0,40 \pm 0,009 * * *$ & $0,45 \pm 0,009 * * *$ & $0,43 \pm 0,008 * * *$ \\
\hline \multicolumn{6}{|c|}{ АсAТ, ммоль/г/л } \\
\hline $\mathrm{K}$ & $4,27 \pm 0,18$ & $4,30 \pm 0,18$ & $4,29 \pm 0,17$ & $4,35 \pm 0,15$ & $4,33 \pm 0,13$ \\
\hline Д1 & $4,31 \pm 0,13$ & $4,49 \pm 0,15$ & $4,82 \pm 0,20$ & $5,14 \pm 0,19 * *$ & $4,93 \pm 0,24^{*}$ \\
\hline Д2 & $4,28 \pm 0,17$ & $4,60 \pm 0,19$ & $5,16 \pm 0,23 * *$ & $5,70 \pm 0,21 * * *$ & $5,54 \pm 0,25 * * *$ \\
\hline
\end{tabular}

При дослідженні активності аспартатамінотрансферази, встановлено, що на початку досліду вона у сироватці крові контрольної да двох дослідних груп коливалася у межах 4,27 $\pm 0,18$ $4,31 \pm 0,13$ ммоль/г/л. Після випоювання води 3 сульфатом кадмію встановлено підвищену активність даного ензиму вже починаючи 37 доби досліду. На 14 добу досліду встановлено підвищення активності АсАТ у сироватці крові курей, яким задавали сульфат кадмію у дозі 2 мг/кг маси тіла, на 12,4\% відповідно. Дещо нижчою активність ензиму була у сироватці крові курей другої дослідної групи, де відповідно вона зросла до 5,16 \pm 0,23 ммоль/г/л, тоді як у контрольної групи даний показник коливався у межах 4,29 \pm 0,17 ммоль/г/л. На 21 добу досліду активність АсАТ у сироватці курей обох дослідних груп продовжувала зростати і відносно показників контрольної групи курей зросла на 18,2 і 31\% відповідно.

На 30 добу досліду активність ензиму АсАТ порівняно $з$ попередньою добою почала знижуватися до $4,93 \pm 0,24$ і 5,54 $\pm 0,25$ ммоль/г/л.

Висока активність амінотрансфераз у сироватці крові курей за кадмієвого навантаження вказує на деструктивні процеси у печінці, які спричиняють збільшення виходу амінотрансаміназ 3 клітинних органел у крові дослідної птиці. Таким чином, одержані результати вказують про посилення деструктивних процесів в організмі курей за кадмієвого навантаження.

Слід також відзначити, що активність аланінамінотрансферази зростала більшою мірою чим активність аспартат-амінотрансферази. Це пов'язано 3 тим, що АлАТ навіть при незначних деструктивних ураженнях мембран гепатоцитів за кадмієвого навантаження, легко виділяється 3 них і надходить у кров, тоді як АсАТ міститься у мітохондріях гепатоцитів, а тому проникнення даного ензиму у кров ускладнюється ще й тим, що крім поверхневої оболонки клітини, даний ензим повинен проникнути ще й через мітохондріальну мембрану, що буває при високих дозах кадмію.

\section{Висновки}

Випоювання курям-несучкам сульфату кадмію у дозах 2 і 4 мг/кг маси тіла, сприяло порушенню функ- 
ціонального стану печінки, на що вказує підвищена активність амінотрансфераз у їх сироватці крові;

Активність аланін- та аспартат-амінотрансферах була вищою у сироватці крові курей другої дослідної групи на 21 та 30 добу досліду.

\section{References}

Al-Azemi, M., Omu, F.E., Kehinde, E.O., Anim, J.T., Oriowo, M.A., \& Omu, A.E. (2010). Lithium protects against toxic effects of cadmium in the rat testes. J. Assist. Reprod. Genet, 27(8), 469-476. doi: 10.1007/s10815-010-9426-3.

Ali, M.M., Murthy, R.C., \& Chandra, S.V. (1986). Developmental and longterm neurobehavioral toxicity of low-level in utero $\mathrm{Cd}$ exposure in rats. Neurobehavioral Toxicology and Teratology, 8(5), 463-468. https://www.ncbi.nlm.nih.gov/pubmed/3785508.

Antonio, M.T., Benito, M.J., Leret, M.L., \& Corpas, I. (1998). Gestation administration of cadmium alters the neurotransmitter levels in newborn rat brains. J Appl Toxicol., 18(2), 83-88. https://www.ncbi.nlm.nih.gov/pubmed/9570689.

El-Refaiy, A.I., \& Eissa, F.I. (2012). Protective effects of ascorbic acid and zinc against cadmium-induced histopathological, histochemical and cytogenetic changes in rats. Comunicata Scientiae, 3(3), 162-180. https://www.comunicatascientiae.com.br/comunicata/a rticle/view/186/136.

El-Shahat, A.E., Gabr, A., Meki, A.R., \& Mehana, E.S. (2009). Altered testicular morphology and oxidative stress induced by cadmium in experimental rats and protective effect of simultaneous green tea extract. Int. J. Morphol., 27(3), 757-764. doi: 10.4067/S071795022009000300020 .

Fregoneze, J.B., Marinho, C.A., Soares, T., Castro, L., Sarmento, C., Cunha, M., Gonzalez, V., Oliveira, P., Nascimento, T., Luz, C.P., Santana, Jr. P., DeOliveira, I.R., \& e-Castro-e-Silva, E. (1997). Lead $(\mathrm{Pb} 2+)$ and cadmium $(\mathrm{Cd} 2+)$ inhibit the dipsogenic action of central beta-adrenergic stimulation by isoproterenol. Brazilian Journal of Medical and Biological Research, 30(3), 419-423. doi: 10.1590/S0100879X1997000300018.

Grushanska, N. (2017). The content of heavy metals in the cow hair of the northern-eastern biogeochemical zone. Scientific Messenger of LNU of Veterinary Medicine and Biotechnologies, 19(73), 154-158. doi: 10.15421/nvlvet7332.

Gutyj, B., Hufriy, D., Binkevych, V., Vischur, V., Binkevych, O., \& Kurlyak, I. (2015). The changes of biochemical and morphological indices of rats' blood under chronic cadmium toxicosis. Scientific Messenger of LNU of Veterinary Medicine and Biotechnologies, 17(3), 120-123. Retrieved from https://nvlvet.com.ua/index.php/journal/article/view/5 31.

Gutyj, B.V., Gufrij, D., Binkevych, V., Binkevych, O., Kurlyak, I., \& Sobolta, A. (2015). Influence of Mevesel \& E-selenium on level of intermediate and final products of lipid peroxidation in bulls' blood after cadmium loading. Scientific Messenger of LNU of Veterinary Medicine and Biotechnologies, 17(1), 190 194. Retrieved from https://nvlvet.com.ua/index.php/ journal/article/view/292.

Gutyj, B.V. (2015). The activity of antioxidant protecting of the bulls for acute cadmium toxicosis. Scientific Messenger of LNU of Veterinary Medicine and Biotechnologies, 17(1), 31-36. Retrieved from https://nvlvet.com.ua/index.php/journal/article/view/2 14.

Gutyj, B. (2015). The influence of hydravite-e, e-selenium on activity of aminotransferases in bulls blood serum by chronic cadmium toxicosis. Scientific Messenger of LNU of Veterinary Medicine and Biotechnologies. Series: Veterinary Sciences, 17(2), 43-47. Retrieved from https://nvlvet.com.ua/index.php/journal/article/ view/458

Gutyj, B.V., Binkevych, V., \& Binkevych, O. (2016). Hematological changes of rats after cadmium toxicosis. Scientific Messenger of LNU of Veterinary Medicine and Biotechnologies, 18(1), 165-167. Retrieved from https://nvlvet.com.ua/index.php/journal/article/view/11 0 .

Gutyj, B.V., Murs'ka, S.D., Gufrij, D.F., Hariv, I.I., Levkivs'ka, N.D., Nazaruk, N.V., Gajdjuk, M.B., Pryjma, O.B., Bilyk, O.Ja., \& Guta, Z.A. (2016). Influence of cadmium loading on the state of the antioxidant sys-tem in the organism of bulls. Visnyk of Dniprope-trovsk University. Biology, ecology, 24(1), 96-102. doi:10.15421/011611.

Gutyj, B., Martyshchuk, T., Bushueva, I., Semeniv, B., Parchenko, V., Kaplaushenko, A., Magrelo, N., Hirkovyy, A., Musiy, L., \& Murska, S. (2017). Morphological and biochemical indicators of blood of rats poisoned by carbon tetrachloride and subject to action of liposomal preparation. Regulatory Mechanisms in Biosystems, 8(2), 304-309. doi: 10.15421/021748.

Gutyj, B., Grymak, Y., Drach, M., Bilyk, O., Matsjuk, O., Magrelo, N., Zmiya, M., \& Katsaraba, O. (2017). The impact of endogenous intoxication on biochemical indicators of blood of pregnant cows. Regulatory Mechanisms in Biosystems, 8(3), 438-443. doi: 10.15421/021768.

Gutyj, B., Hariv, I., Gunchak, V., Sobolta, A., Prijma, O., \& Iesina, E. (2018). The influence of «Amprolinsile» and brovitacoccide on the activity of blood serum enzymes by the eumeriosic invasion. Scientific Messenger of Lviv National University of Veterinary Medicine and Biotechnologies. 20(83), 51-55. doi: $10.15421 /$ nvlvet8310.

Hariv, M.I., \& Gutyj, B.V. (2016). Vplyv liposomalnoho preparatu Butaintervit na proteinsyntezuvalnu funktsiiu pechinky shchuriv za otruiennia tetrakhlormetanom [Influence of the liposomal preparation Butaintervite on protein synthesis function in the livers of rats under the influence of carbon tetrachloride poisoning]. Visnyk of Dnipropetrovsk University. Biology, medicine, 7(2), 123-126. doi: 10.15421/021622 (in Ukrainian). 
Hradovych, N., Paranyak, R., \& Zabytivskyi, Y. (2016). Influence of zeolites on lead and cadmium content in separate links of trophic chain in hydroecosystems. Scientific Messenger of LNU of Veterinary Medicine and Biotechnologies, 18, 2(67), 61-65. doi: $10.15421 /$ nvlvet6714.

Hutyi, B.V. (2013). Riven pokaznykiv nefermentnoi systemy antyoksydantnoho zakhystu orhanizmu bychkiv za umov kadmiievoho navantazhennia. Naukovyi visnyk Lvivskoho natsionalnoho universytetu veterynarnoi medytsyny ta biotekhnolohii im. Gzhytskoho, 15, 1(4), 40-45. Rezhym dostupu: http://nbuv.gov.ua/UJRN/nvlnu_2013_15_1(4)_10 (in Ukrainian).

Hutyi, B.V. (2013). Vmist vitaminiv A i E u krovi bychkiv za umov kadmiievoi intoksykatsii. Visnyk Sumskoho natsionalnoho ahrarnoho universytetu. Seriia: Veterynarna medytsyna, 2, 31-33. Rezhym dostupu: http://nbuv.gov.ua/UJRN/Vsna vet 2013210 (in Ukrainian).

Hutyi, B.V. (2013). Vplyv E-selenu na aktyvnist hlutationovoi systemy antyoksydantnoho zakhystu orhanizmu buhaitsiv pry kadmiievomu navantazhenni. Visnyk Sumskoho natsionalnoho ahrarnoho universytetu. Seriia: Veterynarna medytsyna, 9, 70-73. Rezhym dostupu: http://nbuv.gov.ua/UJRN/Vsna_vet_2013_9_22 (in Ukrainian).

Hutyi, B.V. (2013). Vplyv E-selenu na vmist vitaminiv A i E u krovi bychkiv za umov kadmiievoi intoksykatsii. Naukovyi visnyk Lvivskoho natsionalnoho universytetu veterynarnoi medytsyny ta biotekhnolohii im. Gzhytskoho, 15, 3(3), 311-314. Rezhym dostupu: http://nbuv.gov.ua/UJRN/ nvlnu $2013 \quad 15 \quad 3(3) \quad 55$ (in Ukrainian).

Hutyi, B.V. (2013). Vplyv khlorydu kadmiiu u riznykh dozakh na aktyvnist aminotransferaz syrovatky krovi buhaitsiv. Naukovyi visnyk Lvivskoho natsionalnoho universytetu veterynarnoi medytsyny ta biotekhnolohii im. Gzhytskoho, 15, 1(1), 49-52. Rezhym dostupu: http://nbuv.gov.ua/UJRN/nvlnu_2013_15_1(1)_11 (in Ukrainian).

Hutyi, B.V. (2013). Vplyv khlorydu kadmiiu u toksychnykh dozakh na hlutationovu systemu antyoksydantnoho zakhystu orhanizmu bychkiv. Veterynarna biotekhnolohiia, 22, 112-116. Rezhym dostupu: http://nbuv.gov.ua/UJRN/vbtb_2013_22_23 (in Ukrainian).

Hutyi, B.V. (2013). Vplyv Meveselu na pokaznyky neenzymnoi systemy antyoksydantnoho zakhystu orhanizmu buhaitsiv za umov kadmiievoho navantazhennia. Biolohiia tvaryn, 15(3), 16-21. Rezhym dostupu: http://nbuv.gov.ua/UJRN/bitv_2013_15 34 (in Ukrainian).

Hutyi, B.V. (2013). Vplyv meveselu na vmist vitaminiv A i E u krovi bychkiv za umov kadmiievoi intoksykatsii. Naukovyi visnyk Lvivskoho natsionalnoho universytetu veterynarnoi medytsyny ta biotekhnolohii im. Gzhytskoho, 15, 3(1), 78-82. Rezhym dostupu:
http://nbuv.gov.ua/UJRN/nvlnu_2013_15_3(1)_18 (in Ukrainian).

Hutyi, B.V. (2013). Vplyv meveselu ta E-selenu na riven pokaznykiv ne fermentnoi systemy antyoksydantnoho zakhystu orhanizmu buhaitsiv pry kadmiievomu navantazhenni. Veterynarna medytsyna, 97, 419-421. Rezhym dostupu: http://nbuv.gov.ua/UJRN/ vetmed_2013_97_172 (in Ukrainian).

Khariv, M., Gutyj, B., Butsyak, V., \& Khariv, I. (2016). Hematological indices of rat organisms under conditions of oxidative stress and liposomal preparation action. Biological Bulletin of Bogdan Chmelnitskiy Melitopol State Pedagogical University. 6 (1), 276-289. doi: $10.15421 / 201615$.

Liu, J., Qian, S.Y., Guo, Q., Jiang, J., Waalkes, M.P., Mason, R.P., \& Kadiiska, M.B. (2008). Cadmium generates reactive oxygen- and carbon-centered radicalspecies in rats: Insights from in vivo spintrappingstudies. Free Radic Biol Med., 45(4), 475481. doi: 10.1016/j.freeradbiomed.2008.04.041.

Lu, J., Jin, T., Nordberg, G., \& Nordberg, M. (2005). Metallothionein gene expression in peripheral lymphocytes and renal dysfunction in a population environmentally exposed to cadmium. Toxicol Appl Pharmacol 206(2), 150-156. doi: 10.1016/j.taap.2004.12.015.

Nazaruk, N., Gutyj, B.V., \& Hufriy, D. (2015). Influence of metifen and vitamix se on the activity of aminotransferases of bulls blood serum at cadmium nitrate loading. Scientific Messenger of LNU of Veterinary Medicine and Biotechnologies, 17(1), 121126. Retrieved from https://nvlvet.com.ua/index.php/ journal/article/view/231.

Ostapyuk, A.Y., \& Gutyj, B.V. (2018). Influence of cadmium loading on morphological parameters of blood of the Laying Hens. Scientific Messenger of Lviv National University of Veterinary Medicine and Biotechnologies, 20(88), 48-52. doi: $10.32718 /$ nvlvet 8808 .

Pavan Kumar, G., \& Prasad, M.N.V. (2004). CadmiumInducible Proteins in Ceratophyllum demersum L. (a Fresh Water Macrophyte): Toxicity Bioassays and Relevance to Cadmium Detoxification. Bulletin of Environmental Contamination and Toxicology, 73(1), 174-181. doi: 10.1007/s00128-004-0410-4.

Peng, L., Wang, X., Huo, X., Xu, X., Lin, K., Zhang, J., Huang, Y., \& Wu, K. (2015). Blood cadmium burden and the risk of nasopharyngeal carcinoma: a casecontrol study in Chinese Chaoshan population. Environmental Science and Pollution Research, 22(16), 12323-12331. doi: 10.1007/s11356-015-4533-4.

Rodríguez, E.M., Bigi, R., Medesani, D.A., Stella, V.S., Greco, L.S.L., Moreno, P.A.R., Monserrat, J.M., Pellerano, G.N., \& Ansaldo, M. (2001). Acute and chronic effects of cadmium on blood homeostasis of an estuarine crab, Chasmagnathus granulata, and the modifying effect of salinity. Brazilian Journal of Medical and Biological Research. 34(4), 509-518. https://www.ncbi.nlm.nih.gov/pubmed/11285463.

Sachko, R.G., Lesyk, Ja.V., Luchka, I.V., \& Nevostruyeva, I.V. (2016). Contents of heavy metals 
in food, organism and animal products in the Zacarpathian biogeochemical province. Scientific Messenger LNUVMBT named after S.Z. Gzhytskyj, 18, 3(71), 87-90. doi: 10.15421/nvlvet7120.

Salvatori, F., Talassi, CB, Salzgeber, S.A., Sipinosa, H.S., \& Bernardi, M.M. (2004). Embryotoxic and long-term effects of cadmium exposure during embryogenesis in rats. Neurotoxicology and Teratology, 26(5), 673680. doi: 10.1016/j.ntt.2004.05.001.

Uetani, M., Kobayashi, E., Suwazono, Y., Okubo, Y., Honda, R., Kido, T., \& Nogawa, K. (2005). Selenium,
Cadmium, Zinc, Copper, and Iron Concentrations in Heart and Aorta of Patients Exposed to Environmental Cadmium. Bulletin of Environmental Contamination and Toxicology, 75(2), 246-250. doi: 10.1007/s00128-005-0744-6.

Vlizlo, V.V. (2012). Laboratorni metody doslidzhen u biolohiyi, tvarynnytstvi ta veterynarniy medytsyni [Laboratory methods of investigation in biology, stock-breeding and veterinary]. Spolom, Lviv (in Ukrainian). 